\title{
SOCIAL MARKETING IN PROMOTING HEALTH BEHAVIOR: A ROLE OF PSYCHOLOGICAL SET
}

\author{
Conny Tjandra R \\ Sekolah Tinggi Ilmu Ekonomi Yayasan Keluarga Pahlawan Negara \\ e-mail: conny.ykpn@gmail.com \\ Jofi Puspa \\ Department of Agricultural Economics, Food Economics and Marketing-Management \\ Justus Liebig University. Giessen. Germany. \\ e-mail: jofipuspa@yahoo.de
}

\begin{abstract}
Increasingly incidences of nutrition related diseases such as cardiovascular diseases, obesity and cancers are becoming significant health burdens not only in western countries but it is also newly coming health problem in Asia, including Indonesia. To encounter this development in the future it is important to continually promote the diseases prevention actions through appropriate social marketing programs. For that purpose, understanding psychological set such as knowledge, belief, attitude and motivation to perform diseases prevention actions and their causal relationship is becoming more and more important. The most challenging issue is to perform social marketing programs that can successfully influence people future health behavior. Our study has aim to understand the relationship of some psychological factors in influencing behavior. The result of this study showed that in spite of controversial issues published in current studies, we found that inherent knowledge level influences motivation through a modulation of attitude variable.
\end{abstract}

Keywords: eating behavior, knowledge, attitude, motivation, behavioral action, prevention, healthy eating habit.

\begin{abstract}
Abstrak
Meningkatnya jumlah penyakit kronik yang berhubungan dengan gizi pangan seperti penyakit jantung koroner, kegemukan dan kanker merupakan masalah kesehatan yang utama bukan hanya di Negara barat saja melainkan juga terjadi di negara berkembang seperti Asia. Untuk mengatasi masalah ini, perlu dikembangkan sistem pencegahan yang dapat dilakukan oleh setiap individu didalam masyarakat. Pendidikan dan penyuluhan kepada masyarakat terhadap pentingnya tindakan preventif seperti melalui "social marketing programs" yang digalakkan baik oleh pemerintah atau institusi kesehatan lainnya, sangatlah penting. Didalam social marketing, promosi tentang pencegahan semestinya dilakukan dengan terlebih dahulu mengetahui dan mengenal segala macam bentuk kebutuhan dasar, pengetahuan, sikap, kepercayaan dan faktor psikologi lainnya dari masyarakat. Studi ini bertujuan untuk mengetahui peran pengetahuan nutrisi, sikap dan motivasi masyarakat Indonesia (Jawa) terhadap upaya pencegahan penyakit kronik. Salah satu hasil utama dari penelitian ini menunjukkan bahwa pengetahuan dasar konsumen akan mempengaruhi motivasi secara tidak langsung melalui pembentukan sikap konsumen.
\end{abstract}

Kata Kunci: perilaku konsumen, motivasi, pengetahuan,sikap, pencegahan penyakit, pola makan sehat.

\section{INTRODUCTION}

In spite of a large body of scientific evidence proving the role of dietary changes as disease prevention measure, abundant healthy eating campaign materials and intensive health education agendas people's intentional motivation to pursue a healthy eating pattern is still a problem. Consequently, it can be noticed that dis- 
eases associated with unhealthy diet patterns, such as cardiovascular disease, obesity and diabetes are sharply increasing worldwide. Therefore, nowadays it is very important to understand more about the basic people' mind in influencing their future decision making process. In the case of making a health- and healthy diet decision making process a sufficient knowledge on behavioral science plays salient role in explaiing the success of many dietary campaigns (social marketing campaigns on healthy diet programs) and diseases prevention measurements. However, diet behavior change is understood to be complex and involved multidisciplinary approaches. Understanding diet behavior requires knowledge on psychological set, economics and nutrition sciences. The inherent psychological set is a bundle of person's mental functions and behaviors which includes personal's attitude toward-, belief in-, motivation to-, and perception on- and knowledge on health prevention and healthy eating habits. Unfortunately, the most published studies are mainly attempted to find out and reveal each individual causal. Till now no consensus has been reached on how to explain comprehensively and precisely how and why people subject to a certain behavioral coercion. A very limited multidisciplinary study has been done so far.

Therefore, in this study we intended to perform a basic thought which is based on multidisciplinary approaches. This study focused on finding out the most influential indicators underlying rational and irrational behavior and to depict the relationship between those indicators and volition of action. This paper has two main aims: (1) to understand people's nutrition knowledge and attitude toward disease prevention, and (2) to lace systematically the roles of and causal relationship between consumers' nutrition knowledge and attitude in persuading inherent intentional motivation to pursue disease prevention action through a healthy diet behavior. Indirectly, this paper studied and analyzed the four models analogous to the Schwartz models.

\section{THEORETICAL BACKGROUND}

Many researchers show that the role of nutrition knowledge in influencing behavior is still controversial. In most studies nutrition knowledge is only weakly associated with healthful dietary behavior (Douglas and Douglas, 1984; Perron and Endres, 1985; Kristal et al., 1990; Packman and Kirk, 2000). Nutrition knowledge is probably a necessary, but not a sufficient condition for healthful dietary behavior (Glanz, 1985). Furthermore, no significant correlations were found between BMI (Body Mass Index) and total nutrition score (O'Brien and Davies, 2007). According to Pierce et al. (1984) many people know about healthful dietary behavior, but are unable or unwilling to adopt them. Other studies found a weak correlation between nutrition knowledge and actual choices of healthy food (Story and Resnick, 1986; Halverson, 1987). Adolescents' knowledge about healthy eating isn't the only determinant for their food choices; and so traditional nutritional interventions focusing on concepts about healthy eating should be modified, aiming at behavioral changes (Leme et al., 2011). Regardless of those negative findings nutrition knowledge is never ignored and forgotten and still considered an important factor determining healthful dietary behavior.

In contrast to the above mentioned findings other studies confirmed a positive association between knowledge, healthful dietary behavior (Saegert and Young, 1983; Read et al., 1988) and healthy eating (Wardle et al., 2000). Some researches have demonstrated that increasing nutrition knowledge has only a very moderate effect on behavior (Rasanen et al., 2003; Crites and Aikman, 2005). Nutrition knowledge has been shown to have a positive impact on the selection of healthy foods (Cho and Fryer, 1974; Majem et al., 2007) in studies of the eating behavior of seventh and eighthgrade students (Pirouznia, 2001), of weight loss programs (Klohe-Lehman et al., 2006; Jeffery and Wing, 1995) and also in a weight loss program in low-income and overweight women (Domel et al., 1992 a \& b; Boulanger et al., 2002, Klohe-Lehman et al., 2007). Results also indicated that adults' knowledge on "relationship between diet and disease" and "comparison of foods in terms of specific nutrients" is acceptable. Significant differences were found among gender and age groups. Females of most age groups are better than males in many aspects of nutrition knowledge, attitude and behavior except emotional and external eating behavior. Young (age 19-30) and prime (age 
31-44) adults have better knowledge than that of middle adults (age 45-64) (Lin et al., 2011).

Moreover, it is associated with healthier life style practices, and lower total cholesterol (Pon et al., 2006). In a national US sample of adults Harnack et al. (1997) showed that fat, fibre, fruit and vegetable intakes were closer to dietary recommendations among respondents who had more cancer-prevention knowledge. In a Taiwan sample, inadequate diet and nutrition can slow growth in childhood and increase the risk of health conditions such as obesity, hypertension, and certain cancer in childhood (Chen et al., 2009). Early childhood is now recognized as a key target in the prevention of overweight and obesity, and the knowledge that children gain at this time about food and its health benefits may have an important influence on their dietary choices and preferences in later life (Zarnowiecki et al., 2010)

Some criticisms have been put forward in order to explain this ongoing debate. Some researchers suggest that the poor relationship between knowledge and behavior can be explained by inaccurate measurement of knowledge (Worsely, 2002; Wardle et al., 2000; Anderson et al., 2002). Statistical analysis normally used in those studies, i.e. analyzing the strength of the relationship between two direct measured variables, may have different impacts on the result. Most of the studies applying conventional correlation analysis paid less attotion to the grade of the coefficient (Sims, 1978; Pirouznia, 2001; Kristal et al., 1990, Lin and Lee, 2005. It was suggested that people's knowledge is not one-dimensional as a test score, but that it is somewhat structured (Worsley, 2002). Therefore, knowledge level is possible a latent and can not directly determine by a single variable. It is a multivariate construct. More advanced methods of statistical analysis that can be used to detect the relationship of a multivariate construct and latent variables may be more beneficial for such types of analysis.

The other presumption underlying the controversial role of nutrition knowledge is possibly due to the indirect effects of knowledge. Some studies have suggested that nutrition knowledge may influence dietary behavior through nutrition attitudes (Perron and Endres, 1985; Grotkowski and Sims, 1978; Lin and Lee, 2005). This concept was initially proposed by Schwartz (1975). She suggested that nutrition knowledge may exert an indirect effect by influencing attitude. She found a significant correlation between nutritional knowledge and attitude, but there was no significant correlation between nutritional knowledge and practice.

Attitude is defined as a learned predisposition to respond in a consistently favorable and unfavorable manner with respect to a given object (Sarnoff, 1960 and Thurstone, 1931 in Fishbein and Ajzen, 1975). Attitudes develop over time though a learning process affected by family, group influence, information, experience, and personality. Daniel Katz proposed four classifications of attitude functions (Assael, 2003). It is typically viewed as a latent or underlying variable that is assumed to guide or influence behavior. The individual attitude is predisposed toward performing a type of behavior, all of which are either favorable or unfavorable with respect to the object.

The theory of motivation stipulates a distinction between the terminologies of motivation, motive and incentive. In this field both qualitative and quantitative approaches have been used to explain people's motivation level. Motivation is a neural process which impels the organism to some action or goal, the attainment of which results in drive reduction. Motivational processes are inferred from changes in the direction, intensity or persistence of behavior. It is the driving force or energy or power behind behavior (Heckhausen and Heckhausen, 2006). The activation of the process of an individual's motivation to perform a given goal comprises a set of three simultaneous developmental stages (motivational predecision/intention building-, volitional preaction/intention initiation, and volitional action/intention realization stage and intention deactivation). In the first phase or intention preparation/building process people's beliefs in the behavioral action dominates the whole scenario. These salient beliefs about any given behavior are considered to be the prevailing determinants of a person's intention building and initiation stages. This intention building phase together with inherent motive(s) and environmental influences will hypothetically determine the strength of the intention or drive to engage in an action (intention initiation stage). In that stage the internal disposition and environmental cues are being processed as an over- 
all operant of conscience that finally will lead to the execution of action or goal achievement (intention realization). Motivation-operation for making a decision to follow a healthy diet pattern is different from normally performed decision making processes, because it represents a risky decision making process in the context of health prevention measures (e.g. smoking cessation to prevent CHD or taking a vaccination to prevent hepatitis). The consequences of a decision concerning a healthy diet are long term and with a less clear final outcome. It involves a routine (daily) and continuous decision making process. It also involves conscious/unconscious behavioral operations, such as establishing food preferences.

To simplify the possible relationship between knowledge, attitude and motivational or volition of action four constructs can be considered. These constructs are analogous to the theoretical models proposed by Schwartz (1975). The difference is concerning the quality of the relationship between variables. Four relationship models suggested by Schwartz consisted of the followings: (a) attitudes modulate knowledge and intentional actions/practices, (b) knowledge and attitudes interact to influence intentional actions/practices, (c) knowledge and attitudes independently influence practices, and (d) knowledge influences practices both through modulation of attitude and direct effects. Similarly, in the area of consumer's behavior studies most of the psychological factors have been acknowledged as a bundle of important determinants influencing behavior. However, interrelationships between individual factorsremain to be explained.

Health behaviour involves some various issues including both rational and irrational decision making processes. In the future, community behavioural changing is becoming an important issue for community health approach. Community behavioural changing programs are being seen as an appropriate approach to controvert the presence and increasing incidents of chronic diseases such as obesity, cardiovascular diseases, cancer and aids. Such research typically addresses question like: Why do some people engage in regular physical activity like doing sports, while the others do not? Health behaviour programs are usually addressed to change people from negative health behaviour such as smoking, drinking alcohol heavily, eating bad diet etc. into positive health behaviour. However, especially in many western countries, a quite number of community educational campaigns did not meet with the expected goal or reached unsatisfactory results. Campaigns targeted on stopping cigarette smoking are one significant example for that issue. Recently, such community campaign has increasingly in demand. This type of campaigns, that is targeted to change health behaviour, can be classified into one example of social marketing programs.

The Unlike in commercial marketing, in a social marketing the primary beneficiary is society in general. It covers a strategy to create, communicate and deliver a value in order to influence the target audience behavior that benefits society (Kotler and Lee, 2006). The most challenging aspect of social marketing is that relies heavily on understanding how people behave irrationally in a rational decision making process and on rewarding good behavior rather than punishing bad ones through legal, economic, or coercive form of influence. The most fundamental principle of social marketing is to apply a customer orientation to understand barriers target audiences perceive to adopting the desired behavior and benefits they want and believe they can realize (Kotler and Lee, 2006). Understanding target audiences psychological set such as knowledge on health and disease prevention, attitude toward health and motivation to reach positive health behavior is becoming an underlying fundaments for setting up future social marketing.

\section{METHODOLOGY OF THE STUDY}

Respondents were recruited using a convenient snow ball sampling method. Although this study was not designed to represent a nationwide figure and fact, it was still designed to recruit respondents representing the socioeconomic and demographic profiles of the entire population. This study recruited respondents with age above 16 years living in central regions of Java Island, mainly in Jakarta and its surroundings (Bogor, Tangerang and Bekasi) and in Semarang. Exclusion criteria were people with an education background of medicine, pharmacy or nutrition or people working as health professionals. A small incentive was given to respondents with low social income 
for filling in the questionnaire. A total of 615 questionnaires were distributed to the potential participants. Some study supervisors were appointed for coordination of the recruitment process and to control strictly the originality of the filled-in questionnaires. This was done in order to avoid receiving more than one questionnaire from the same person.

A special objective nutrition knowledge questionnaire was designed following the pattern of the general nutrition knowledge questionnaire for adults developed by Parmenter and Wardle (1999). However, some modifications were made, especially by replacing some examples of Western food items such as pasta, muesli, cheese and sausages with analogous items typical for Indonesian food. In total there were 14 multiple choices questions concerning nutrition knowledge and two openended questions concerning disease prevention matters. Following the nutrition knowledge questionnaire developed by Parmenter and Wardle (1999) some issues such as caloric intake (2 questions), protein (3 questions), fat and fatty acids (4 questions), carbohydrates (2 questions), fiber (2 questions), vitamins and minerals (1 question) were included in the questionnaire. For the statistical analysis all of these 14 questions will be scored and summed together. Point will be given when a question is correctly answered. In addition to that objective knowledge test we included a set of subjective knowledge tests (in total of five individual questions) or perceived inherent nutrition and disease prevention knowledge tests in the questionnaire. Both objective knowledge and self assessed knowledge is important for determining some facets of behavior (Brucks, 1985; Park, et al., 1994; Moorman et al., 2004). Questions testing people's prevention knowledge were focused on the issues of prevention of diarrhea and chronic diseases (e.g. coronary heart disease and its risk factors).

Attitude toward general disease prevention measures was measured using a semantic differential scale of attitude model. Using a bipolar rating scale five questions concerning attitude were included in the questionnaire. These five questions about attitude included the following aspects: importance of prevention action for (family and personal) health, importance of prevention action for reducing (family or personal) future health expenditures, impor- tance and usefulness of prevention action for family and personal life.

Meanwhile, intentional motivation (motivation 1) was measured using direct and indirect questioning techniques. For direct measurement the respondents were asked about the presence of motives for pursuing a prevention action and about the amount of energy or drive they will spend to execute a prevention action (how is your intention to pursue a preventive measure such as....in your daily life?). In contrast to the direct questioning technique, the indirect technique determining people's motivation was designed including some indicators of disease prevention action, such as recording respondents' sport activities, smoking behavior, consumption of supplements and healthy foods and searching healthy diet information behavior (non-medical preventive action) and some medical aided preventive actions such as visiting dentists and a general practice for regular preventive care and medical check-ups. Those indicators were labeled as determinant factors of people's motivation (motivation 2).

Path analysis using a Structural Equation Model (AMOS version 7) was employed to analyze some possible causal relationships between nutrition knowledge, attitude and intetional variables. ANOVA was used to detect significant mean differences between two different groups.

\section{RESULTS}

\section{Respondents' Characteristics}

A total of 409 filled- in questionnaires were collected and analyzed. The summary of respondent profiles is presented in Table 1. $51.5 \%$ of the respondents were male. The age distribution of the respondents represented the age distribution of the Indonesian population, where young- and reproductive age people dominate the population. This study recruited $64.1 \%$ respondents with an age between 20-34 years. We also recruited respondents with lower education backgrounds, such as grade school graduates (9\%), some high school graduates $(50.6 \%)$ and $38.9 \%$ respondents with higher education background (some college, college, master, PhD). Most of them (69.9\%) were employees of different firms or institutions or running a private business. The rest of 
the respondents were housewives, students, or jobless people. $40.3 \%$ of the respondents can be classified as low income class with having an income of less than Rp. 1 Million (or 71€) per month and the rest can be classified as medium to high income classes. $63.8 \%$ of the respondents had a normal BMI, $21.3 \%$ can be classified as an underweight group with BMI less than 19 , and $8.5 \%$ were classified as overweight and obese.

\section{Nutrition Knowledge}

In general, this study showed that the respondents' objective nutrition knowledge was relatively poor and unsatisfactory. The mean value of the total objective knowledge score was only 15.5 out of 30 as a maximum score. Whereas $45.5 \%$ of respondents had a 'bad' score (with a total score of less than 15 points), $43.5 \%$ had a good score (between 16 and 20 points) and only $11 \%$ had a very good score (higher than
20 points). Basically, most of the respondents understood the general questions about fat, carbohydrate, protein and calories. They could provide correct answers to the questions concerning which kind of food contains protein, carbohydrates, fat and fiber, respectively. They had a relatively good knowledge of fat and the different fatty acid species (saturated, unsaturated, omega-9, omega-6 and omega-3 fatty acids). However, knowledge of calcium, fiber and carbohydrates was at a lower level than that of fat. The result of the total objective knowledge score was comparable to the result of the subjective knowledge tests. From the subjective knowledge test, only a few respondents perceived themselves to be knowledgeable about the relevant issues of general nutrition $(23.7 \%)$ and healthy foods (34.5\%). The rests were either labeled themselves with having less knowledge or unknowledgeable.

Table 1: Respondents' characteristics: frequency distribution

\begin{tabular}{|c|c|}
\hline Gender & Male $(51.5 \%)$, Female $(48.5 \%)$ \\
\hline Age distribution & $<19(5.1 \%), 20-34(64.1 \%), 35-49(23.2 \%), 50-64(5.1 \%),>65(0.2 \%)$ \\
\hline Education & $\begin{array}{l}\text { No school }(0.7 \%) \text {, Grade school }(9 \%) \text {, Some high school }(15,4 \%) \text {, } \\
\text { High school }(35.2 \%) \text {, Some college }(5.4 \%) \text {, College/student }(19.6) \text {, } \\
\text { College graduated }(10.5 \%) \text {, Master graduated }(3.4 \%)\end{array}$ \\
\hline Occupation & $\begin{array}{l}\text { Employee }(57.2 \%) \text {, Housewife }(3.4 \%) \text {, Private }(12.7 \%) \text {, Student } \\
(21.5 \%) \text {, Jobless }(1.2 \%) \text {, and Government staffs }(1.7 \%)\end{array}$ \\
\hline Income (in Rp) & $\begin{array}{l}<499 \mathrm{~T}(8.8 \%), 500-999 \mathrm{~T}(31.5 \%), 1.0-4.9 \mathrm{M}(22.7 \%), 5.0-9.9(4.6 \%), \\
10-14.9 \mathrm{M}(0.2 \%), 15-19.9 \mathrm{M}(1.5 \%),>20 \mathrm{M}(1.5 \%)\end{array}$ \\
\hline BMI (WHO classification) & $<19(21.3 \%), 19.1-25(63.8 \%), 25.1-30(7.1 \%), 30.1-40(1.2 \%)$ \\
\hline
\end{tabular}

Table 2: ANOVA test of total objective knowledge score and other variables (demographic and economic variables)

\begin{tabular}{|c|c|c|c|c|}
\hline Variables & $\mathbf{N}$ & Mean value & SD & F (significance) \\
\hline Education background & 401 & & & $126.824 * *$ \\
\hline - lower education (up to senior high school) & 242 & 13.76 & 4.20 & \\
\hline $\begin{array}{l}\text { - higher education (some college, college, mas- } \\
\text { ter and doctor degree) }\end{array}$ & 159 & 18.25 & 3.38 & \\
\hline Income & 288 & & & $54.155^{* *}$ \\
\hline - low income (<1 Million Rupiah) & 164 & 13.21 & 4.29 & \\
\hline - higher income ( $\geq 1$ Million Rupiah) & 124 & 16.87 & 4.00 & \\
\hline Gender & 406 & & & 0.003 \\
\hline - male & 209 & 15.51 & 4.50 & \\
\hline - female & 197 & 15.53 & 4.49 & \\
\hline
\end{tabular}

** Significance values with 5\% probability of error 
Table 2 presents the ANOVA test comparing the total score of knowledge and some demographic-economical variables of the respondents. The result of this ANOVA test showed that there was a significant difference in terms of total objective knowledge score between low and high education respondents and between respondents with low and sufficient income. Respondents with low education tended to be less knowledgeable than the ones with better or higher education background. Similarly, respondents with low income tended to have a lower knowledge score than respondents with a better profile of income. However, there was no difference in terms of knowledge level between male and female respondent groups.

\section{Attitude and Motivation}

Attitude score was calculated by adding all score quoted by the respondents on the five semantic differential scales. Attitude was classified into three levels (negative-, neutral and positive attitude) by using a percentile 25 statistic distribution. The result showed that $17.1 \%$ of the respondents have had a negative attitude towards diseases prevention measurement, $54.5 \%$ have had a neutral attitude and $28.4 \%$ have a positive one. Most of the respondents were mainly having a neutral attitude to highly in fever of disease prevention action presented in the questionnaire. They were more or less in agreement that prevention was useful and im- portant for the self and family health status, and prevention action will reduce future health cost and burdens.

Motivation score were established by summarizing all score of motivation indicators (intentional on doing a non-direct and on direct prevention action). There were at least two group of motivation indicators i.e. direct questioning technique and indirect (through some health preventive actions parameters). In the direct method respondents showed their personal intentional level to preventive action. Similarly to scoring method of attitude scale, a quartile distribution was used. Direct motivation method showed that $47,2 \%$ of the respondents stated to have a high intention to perform preventive action, while $12.2 \%$ and $5,6 \%$ have medium and low intentional level respectively. The finding of indirect questioning techniques showed different results. Based on this result, respondents were be classified into the three groups i.e. having a low-, medium-, and high motivation. There was $71,9 \%$ of respondents having a low motivation, $24,4 \%$ with medium motivation and $3.7 \%$ of the respondents having a high motivation. Apparently, most of the respondents paid less attention of doing medical check-up, routinely doing physical activities, tending not to avoid smoking and low interest on searching information about healthy diet. Until this point we can argue that intentional level is not in line with motivational actions.

Table 3: ANOVA test of total motivation score and other variables (demographic and economic variables)

\begin{tabular}{lcccc}
\hline \multicolumn{1}{c}{ Variables } & N & Mean value & SD & F (significance) \\
\hline $\begin{array}{l}\text { Education background } \\
\text { - low education (up to senior high }\end{array}$ & 403 & & & $96,204^{* *}$ \\
school) & 244 & 6.19 & 4.50 & \\
- high education (some colleague, col- & 159 & 11.18 & 5.64 & \\
league, master and Dr. degree) & & & & \\
Income & 290 & & & $41.953^{* *}$ \\
- low income (< 1 Million Rupiah) & 165 & 5.69 & 3.91 & \\
- good income ( $\geq$ 1 Million Rupiah) & 125 & 9.67 & 6.4 & \\
Gender & 408 & & & \\
- male & 210 & 6.96 & 5.81 & $20.13^{* *}$ \\
- female & 198 & 9.37 & 4.96 & \\
Other: & 407 & & & \\
- smoker & 96 & 3.44 & 4.06 & $57.341^{* *}$ \\
- non smoker & 311 & 9.55 & 5.12 & \\
\hline
\end{tabular}

** Significance value with $5 \%$ probability of error 
Anova test of indirect motivational indicator with respondents' socio-demographical data showed that there were significant differences in terms of motivational actions pursuing disease prevention among respondents with different demographic and economic backgrounds (Table 3). Respondents with a high education profile and high income tended to have a higher motivation score than the ones with low education background and low income profile. The ANOVA test clearly showed that the female group had a higher motivation level than the male group. Similarly, the smoker group tended to have a lower motivation for pursuing general disease prevention than the non-smoker group.

\section{DISCUSSION \\ Knowledge test}

The result of this study stipulated that some segments especially people with low education and economic level still have less knowledge on nutrition and healthy diet. Since the correlation analysis showed that personal knowledge level has a good correlation with attitude and motivation, till this point this study can further suggest the necessity to improve personal knowledge level especially in some segments above mentioned. Because improvement of knowledge level will more or less influence a positive attitude and leverage person's motivation to take diseases prevention actions. For social marketing some interactive campaigns with regard to the basic role of nutrition in preventing chronic diseases are relevant to be implemented. Further a serious social marketing campaign that promotes healthy eating habit is mandatory for the future, considering a rapid growth of nutrition related diseases such obesity and cancer. Regarding the good knowledge of fat and fatty acids we assumed that this knowledge is the result of a controversial impact of a massive food promotion campaign on the issue of avoiding saturated fatty acids (bad fats) and of promoting the consumption of omega-9 and omega-3 fatty acids (good fats), which was initiated by the food industry in late 2000. Unfortunately, in the market place many misleading food product promotion campaigns can be easily found. Those can lead to misleading people's knowledge of nutrition. In such cases the improvement of people's knowledge of nutrition and disease prevention through diet should be targeted not only to shaping people's willingness to change and improve their healthy life style but it should also improve people's decisiveness to react against misleading food advertising. Therefore, improvement of people's knowledge should not mainly be the result of massive commercial information spreading, but it should be the result of intense and continuous education programs provided by nutrition professionals, official nutrition organizations and government institutions.

\section{Attitude and Motivation}

From the frequency distribution this study found a quite number of respondents who have generally positive attitude towards disease prevention measures. They were quit in favor to prevention actions. For this group, they feel doing diseases prevention action is very important and worthy or at least they were not against with the diseases preventive actions. However, a quite high percentage of the respondents showed a neutral attitude towards prevention actions. Probably, they have a little knowledge on the diseases risks or on benefit of doing prevention or they may be insecure that prevention action is economically affordable. A further in depth investigation is necessary to reveal further this issue. With regards to social campaign might be done in the future, this study suggests that a focus need to be done for the community to improve people positive attitude in performing diseases preventive actions.

Measurement of motivation clearly confirmed the finding on attitude scale. The direct motivation question revealed the respondents` subjective intentional motivation to perform prevention actions. The results showed that mostly respondents have a high motivation level. Respondents stated that they were willing to take a preventive measurement in the future. However, the indirect motivation test showed oppositely. Only few of respondents who confirmed to performed positively the prevention indicators such as no smoking, doing sport and medical check-up, taking supplement etc. Mostly people with low income level showed that all prevention actions are not affordable. They are keen to do prevention action, they understood that these prevention actions will provide future benefit and reduce risk of dis- 
eases, but unfortunately, they are not being capable to do so, due to financial limitation. Therefore, intentional motivation is relatively high but behavioral motivation was low. The Attitude scale was more or less in line with intentional motivation scale. Further analysis with regard to the relationship between these three psychological factors will be presented below.

\section{Relationship between Nutrition Knowledge, Attitude and Motivation}

The correlation analysis showed that all indicators of attitude have appositive correlation with the direct indicators of motivation. People who have a positive attitude tended to have higher intentional to perform prevention actions. However, according to the indirect score of motivation, it was a quite low people who were motivated to perform a medical prevention actions such as doing a routine medical and dental check-up, regularly taking supplement, do not smoking and doing a regular physical activities. We need to take a further analysis in order to understand better the clear relationship among all psychological factors. The following is a detailed analysis on the issue of understanding the influence of attitude and knowledge towards motivation.

The second aim of this study was to understand the controversial issue regaring the role of nutrition knowledge and attitude in influencing people's intentional motivation to pursue disease prevention measures through healthy eating actions. First of all, correlation analysis was used to find out the relationship between variables of objective and subjective knowledge together with attitude towards disease prevention and variables indicating people's intentional motivation. Table 4 presents the correlation analyses between individual variables. In general, it seems that correlations of all variables were significantly linear. This was the result of a bivariate correlation analysis. This analysis showed the correlation of pair of two variables. According to this result at this point we can suggest that there is a relationship between variable attitude and motivation, between variable knowledge and motivation and between variable attitude and knowledge. However, these correlations were relatively weak (all coefficient were in the range of 0.122 to 0.369 ). It is difficult to draw the conclusion that knowledge, attitude and motivation have a generally significant relationship with each other. The only moderately significant relationship (coefficient value of 0.505-0.601) was between attitude and the questions directly addressing motivation (motivation 1). Therefore, correlation analysis was problematic.

Path analysis using AMOS to analyze the designed constructs representing the causal relationship between nutritional knowledge, attitude and intentional motivation to pursue disease prevention action as described below.

Table 4: Correlation analysis using Pearson or Spearman-Rho

\begin{tabular}{lccc}
\hline & $\begin{array}{c}\text { Motivation 1 } \\
\text { (direct question) }\end{array}$ & $\begin{array}{c}\text { Motivation 2 (total } \\
\text { score of indicators) }\end{array}$ & $\begin{array}{c}\text { Total score of ob- } \\
\text { jective knowledge }\end{array}$ \\
\hline Subjective knowledge 1 & $0.268^{* *}$ & $0.268^{* *}$ & \\
Subjective knowledge 2 & $0.338^{* *}$ & $0.338^{* *}$ & \\
Subjective knowledge 3 & $0.369 * *$ & $0.369 * *$ & \\
Subjective knowledge 4 & $0.362^{* *}$ & $0.362^{* *}$ & \\
Subjective knowledge 5 & $0.332^{* *}$ & $0.332^{* *}$ & \\
Total score of objective knowledge & $0.240^{* *}$ & $0.339^{* *}$ & 1.000 \\
Attitude 1 & $\mathbf{0 . 5 1 5 * *}$ & $0.122^{*}$ & $0.282^{* *}$ \\
Attitude 2 & $\mathbf{0 . 5 0 5 * *}$ & $0.249^{*}$ & $0.256^{* *}$ \\
Attitude 3 & $\mathbf{0 . 5 8 9 * *}$ & $0.302^{* *}$ & $0.304^{* *}$ \\
Attitude 4 & $\mathbf{0 . 6 0 1 * *}$ & $0.174 * *$ & $0.237^{* *}$ \\
Attitude 5 & $\mathbf{0 . 5 8 5 * *}$ & $0.212^{* *}$ & $0.257^{* *}$ \\
\hline
\end{tabular}

** Correlation is based on 0.01 significance level (2-tails)

* Correlation is based on 0.05 significance level ( 2 tails) 


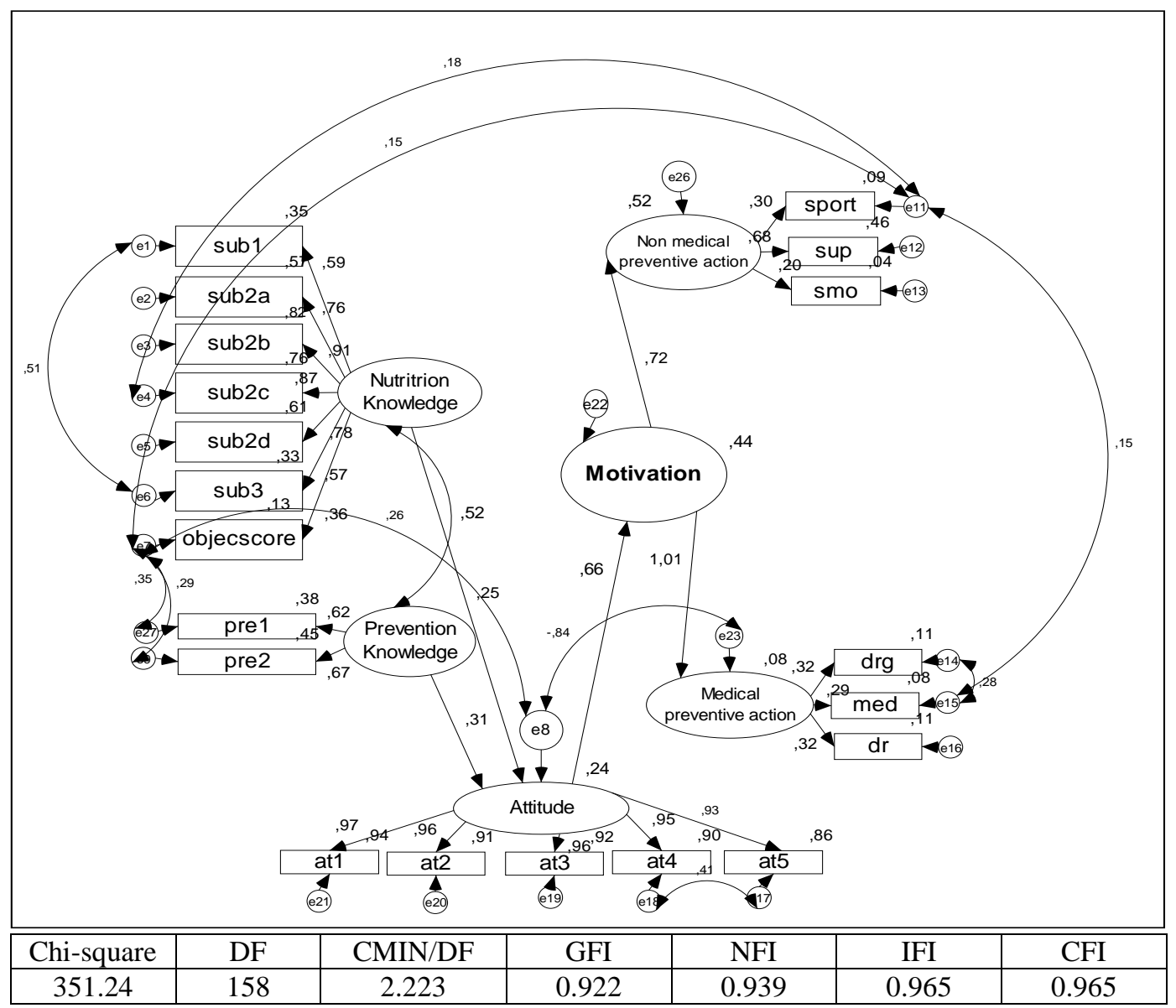

Note:

Sub1-3 : 6 questions on subjective knowledge

Objects score: total of right answers given and summed of 14 questioned used to test the objective knowledge.

At1-5 : attitude questions

Sport 8number of physical activities/week), Sup (taking supplement habit), Smo (number of cigarettes smoked a day): non-medical questions of motivation

drg (number of visit of dentist per year), med (number of medical check-up per year), dr (number of visit to General practitioner per year)

Figure I: A causal analysis of knowledge, attitude and motivation (construct A) using AMOS

The advantage of using SEM (Structure Equation Model) of AMOS because this linear equation model allows us to test some regression analyses at once and to find out which construct is the best model confirming the hypothesis. In this study we have actually analyzed the four volition of action constructs of the possible relationship between knowledge, attitude and motivational as has been suggested by Schwarz (1975). Apparently, only one construct was accepted according to AMOS.

Figure 1 presents only the best model resulting from the analyses of AMOS (the other three constructs were nor shown). The result of AMOS path analysis showed that this construct achieving maximal positive fit. In this construct, it seems that variable attitude modulated the influence of knowledge on intentional motivation to pursue an action. Moreover, AMOS confirmed that without the presence of modulation of attitude, variable knowledge showed only a weak influence on intentional motivation. This statistical finding allows us to suggest that having nutritional knowledge alone is not enough for a person to improve his/her motivation level toward a behavioral change. In- 
herent knowledge should be processed into preferable inherent knowledge and personal belief, in order to able to influence people's attitude. Personal knowledge will have a role in influencing behavior whenever it is converted into personal belief. This personal belief will influence serenity influence people attitude. Finally, as has been confirmed by many studies, attitude will influence people motivation. These numerical figures provided some evidence that (1) the role of knowledge for intentional motivation/intentional action is unimportant in the absence of modulation of attitude, that (2) knowledge influences directly attitude towards an object and that (3) attitude significantly influences intentional behavior. Moreover, the result of analysis with AMOS confirmed that people's intentional motivation significantly influences people's behavior. This study stipulates that a highly positive intentional motivation score will induce people to pursue non-medical prevention actions (betacoefficient of 0.731) and medically aided prevention actions (beta-coefficients of 0.478). Finally, intentional motivation is a strong determinant factor for behavior.

The result of psychological factors analysis presents an evident that promote the role of understanding people psychological set for future social marketing. In the early stage of promoting disease prevention actions, it is important to understand people' current and basic knowledge. Knowledge especially on the issues of nutrition and on the mechanism and influence of nutrition (diet) in causing a disease is always relevant. Emphasis has to be done for improving nutrition knowledge for people with low level of education and low economical level. Promotion and social campaign will leverage people knowledge. A consistent education program on the positive role of doing healthy diet for preventing diseases may beneficial for development of people attitude towards prevention actions. Further, promoting the benefits of doing regular healthy diet and educating the risk of being ignorant of diseases prevention are salient for future community health approaches.

\section{SUMMARY}

This study found that respondents in general display a low to moderate score in objective nutrition knowledge tests. Both objective knowledge- and subjective knowledge tests are important constructs to be used as parameters determining nutrition knowledge. Improvement of people's knowledge on nutrition and healthy diet habit is necessary and it is supposed to be done by official health institutions. Respondents' knowledge of fat and fatty acids was better than that of other topics. People with low educational background and lowincome are the important target segment for future nutrition education programs.

Correlations analysis was not adequate for coming to definite conclusions regarding the relationship between multivariable constructs. This study found that correlations between variables (knowledge, attitude, motivation/intentional action) were all linear and significantly positive, but thatthe c orrelation coefficients were relatively weak (below 0.4 point). According to this result at this point we can suggest that there is a relationship between variable attitude and motivation, between variable knowledge and motivation and between variable attitude and knowledge. However, these correlations were relatively weak.

On the other side an approach using AMOS leads to identical but providing much more meaningful results. It showed that the role of (nutrition and prevention) knowledge for initiating intentional action (intentional motivation) was a positive one, but it is significantly performed through the presence of modulation of attitude towards prevention action. Moreover, intentional motivation significantly influences the non-medical- and medically-aided prevention actions.

For the practical implications these findings indirectly revealed that educational programs and social marketing campaigns designed to improve people knowledge on nutrition and healthy eating are not meaningless for modifying people behavior. Improvement of knowledge is succinctly influencing people's motivation and intentional of action. However, its direct effect will be difficult to be observed. One should consider a whole context including the latent role of knowledge variable in the total construct of behavioral mechanism of action and should understand the role attitude modulation process. 


\section{REFERENCES}

Anderson, AS., A. Bell, A. Adamson and P. Moynihan. 2002. A Questionnaire Assessment of Nutritional Knowledge: Validity and Reliability Issues. Public Health Nutrition. 5(3). 497-503.

Assael, H. 2003. Consumer Bahavior. A Strategic Approach. Boston. Houghton Mifflin Co.

Boulanger, PM., P. Escamila, et al. 2002. Determinants of Nutrition Knowledge among Low-Income Latino Caretakers in Hartford, Conn. Journal of the American Dietetic Association. 102(7). 978-981.

Brucks, M. 1985. The Effects of Product Class Knowledge on Information Search Behavior. Journal of Consumer Research. 12(1). 1-6.

Chen, YH., CY. Yeh, YM. Lai, et al. 2009. Significant Effects of Implementation of Health-Promoting Schools on Schoolteachers' Nutrition Knowledge and Dietary ntake in Taiwan. Public Health Nutrition. 13(4). 579-588.

Cho, M. and BA. Fryer. 1974. What Foods do Physical Education Majors and Basic Nutrition Students Recommend for Athletes? Journal of the American Dietetic Association. 65(5). 541-544.

Crites, SL. and SN. Aikman. 2005. Impact of Nutrition Knowledge on Food Evaluations. European Journal of Clinical Nutrition. 59. 1191-1200.

Domel, S.B., BB. Alford, HN. Cattlett, BE. Gench. 1992. Weight Control for Black Women. Journal of the American Dietetic Association. 92(3). 346-348.

Domel, S.B., BB. Alford, HN. Cattlett, ML. Rodriguez, EG. Barbara. 1992. A Pilot Weight Control Program for Hispanic Women. Journal of American Dietetic Association, 92(10). 1270-1271.

Douglas, P.D. and JG. Douglas. 1984. Nutrition Knowledge and Food Practices of High School Athletes. Journal of the American Dietetic Association. 84(10). 11981202.
Glanz, K. 1985. Nutrition Education for Risk Factor Reduction and Patient Education: a Review. Preventive Medicine. 14(6). 721-752.

Grotkowski, M.L. and LS. Sims. 1978. Nutritional Knowledge, Attitudes, and Dietary Practices of the Elderly. Journal of the American Dietetic Association. 72(5). 499-506.

Halverson, L.S. 1987. Relationships among $\mathrm{Nu}$ trition Knowledge, Attitudes and Behavior of Appalachian Middle School Children. $\mathrm{PhD}$ dissertation. Columbus, $\mathrm{OH}$, The Ohio State University.

Harnack, L., G. Block, A. Subar, et al. 1997. Association of cancer preventionrelated nutrition knowledge, beliefs, and attitudes to cancer prevention dietary behavior. 1992 NHIS cancer epidemiology supplement. Journal of the American Diatetic Association, 97(9). 957-965.

Heckhausen, J. and H.Heckhausen. 2006. Motivation und Handeln. 3rd Edition. Heidelberg. Springer.

Jeffery, R.W. and RR. Wing. 1995. Long-term Effects of Interventions for Weight Loss Using Food Provision and Monetary Incentives. Journal of Consulting and Clinical Psychology. 63(5). 793-796.

Kristal, A.R., DJ. Bowen, SJ. Curry, et al. 1990. Nutrition Knowledge, Attitudes and Perceived Norm as Correlates of Selecting Low-Fat Diets. Health Education Research. 5(4). 467-477.

Klohe-Lehman, D., J. Freeland-Graves, ER. Anderson, et al. 2006. Nutrition Knowledge is Associated with Greater Weight Loss in Obese and Overweight Low-Income Mothers. Journal of the American Dietetic Association. 106(1). 65-75.

Klohe-Lehman, D., J. Freeland-Graves, KK. Clarke, et al. 2007. Low-income, Overweight and Obese Mothers as Agents of Change to Improve Food Choices, Fat Habits, and Physical Activity in Their 1-to-3-year-old Children. Journal of the American College of $\mathrm{Nu}-$ 
trition [J Am Coll Nutr]. 26 (3). 196208.

Kotler, P., and N. Lee (2006) Social Marketing: Influencing Behaviors For Goods. $3^{\text {rd }}$ Edition. California: Sage Publications Inc.

Leme, ACB., ST. Philippi, ECT. Silva. 2011. Association of Brazilian Adolescents with Healthy Eating: Knowledge, Perceptions and Food Choices. Food and Nutrition Science. 2. 1036-1042.

Lin, W and YW. Lee. 2005. Nutrition Knowledge, Attitudes and Dietary Restriction Behavior of the Taiwanese Elderly. Asia Pacific Journal of Clinical Nutrition. 14(3). 221-229.

Lin W., CM. Hang, HC. Yang, MH. Hung. 2011. 2005-2008 Nutrition and Health Survey in Taiwan: The Nutrition Knowledge, Attitude and Behavior of 19-64 years old Adults. Asia Pacific Journal of Clinical Nutrition. 20(2), 309-318.

Majem, LS., BR Vinas, G. Salvador, L. RibasBarba, et al. 2007. Knowledge, Opinions and Behaviors related to Food and Nutrition in Catalonia, Spain (1992 2003). Public Health Nutrition. 10(11a). 1396-1405.

Moorman, C., K. Diehl, D. Brinberg, B. Kidwell. 2004. Subjective Knowledge, Search Locations, and Consumer Choice. Journal of Consumer Research. 31(3). 673-680.

O’Brian, G. and M. Davies. 2007. Nutrition Knowledge and Body Mass Index. Health Education Research. 22(4). 571-575.

Packman, J and SFL. Kirk. 2000. The Relationship between Nutritional Knowledge, Attitudes and Dietary Fat Consumption in Male Students. Journal of Human Nutrition Dietetic. 13(6). 389-395.

Parmenter, K. and J. Wardle. 1999. Development of a General Nutrition Knowledge Questionnaire for Adults. European Journal of Clinical Nutrition. 53(4). 298-308.
Park, CW., DL. Mothersbaugh, L. Feick. 1994. Consumer Knowledge Assessment. Journal of Consumer Research. 21(1). 71-82.

Perron, DK. and J. Endres. 1985. Knowledge, Attitudes and Dietary Practices of Female Athletes. Journal of the American Dietetic Association. 85(5). 573-576.

Pierce, D.K., SJ. Connor, G. Sexton, et al. 1984. Knowledge and Attitude towards Coronary Heart Disease and Nutrition in Oregon Families. Preventive Medicine. 13(4). 390-395.

Pirouznia, M. 2001. The Association between Nutrition Knowledge and Eating Behavior in Male and Female Adolescents in the US. International Journal of Food Science and Nutrition, 52(2). 127-132.

Pon, LW., MY. Noor-Aini, FB. Ong, et al. 2006. Diet, Nutritional Knowledge and Health Status of Urban Middle-aged Malaysian Women. Asia Pacific Journal of Clinical Nutrition, 2006. 15(3). 388-399.

Räsänen M, H. Niinikoski, S. Keskinen, H. Helenius, et al. 2003. Parental Nutrition Knowledge and Nutrient Intake in an Atherosclerosis Prevention Project: The Impact of Child-targeted Nutrition Counselling. Appetite. 41(1). 69-77.

Read, M.H., M. Harveywebster, J. UsingerLesquereux. 1988. Adolescent Compliance with Dietary Guidelines. Adolescence. 23(91). 567-575.

Saegert, J and EA. Young. 1983. Nutrition Knowledge and Health Food Consumption. Nutrition \& Behavior. 1(2). 103113.

Sarnoff, 1960 and Thrustonem, 1931 in Fishbein, M and Ajzen, I. 1975. Belief, attitude, intention and behaviour, an introduction to theory and research, Addison-Wesley- Philippines.

Sims, L. 1978. Dietary Status of Lactating Women. Journal of the American Dietetic Association. 73 (2). 147-154. 
Schwartz, N. 1975. Nutritional Knowledge, Attitudes and Practices of High School Graduates. Journal of the American Dietetic Association. 66(1). 28-31.

Story, M and MD. Resnick. 1986. Adolescents' Views of Food and Nutrition. Journal of Nutrition Education. 18. 188-192.

Wardle, J., K. Parmenter, J. Waller. 2000. Nutrition Knowledge and Food Intake. Appetite, 34(3). 269-275.
Worsley, A. 2002. Nutritional Knowledge and Food Consumption: can Nutrition Knowledge Change Food Behavior? Asia Pacific Journal of Clinical Nutrition, 11(suppl 3). 579-585.

Zarnowiecki. J. Dollman, and N. Sinn. 2011. A Tool for Assessing Healthy Food Knowledge in 5-6-year-old Australian Children. Public Health Nutrition. 14(7). 231-1183. 